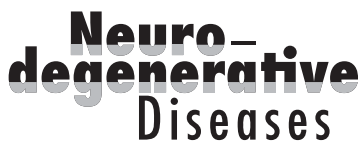

\title{
Cellular Prion Protein Mediates Toxic Signaling of Amyloid Beta
}

\author{
Ulrike K. Resenberger ${ }^{\mathrm{a}}$ Konstanze F. Winklhofer ${ }^{\mathrm{a}, \mathrm{b}}$ Jörg Tatzelt ${ }^{\mathrm{a}, \mathrm{b}}$ \\ ${ }^{a}$ Neurobiochemistry, Adolf-Butenandt Institute, Ludwig Maximilians University Munich, and ${ }^{\mathrm{b}}$ German Center for \\ Neurodegenerative Diseases (DZNE), Munich, Germany
}

\section{Key Words}

Prion - Alzheimer's disease $\cdot \mathrm{N}$-methyl-D-aspartate $\cdot$ Intrinsically disordered $\mathrm{N}$-terminal domain of $\operatorname{PrPC}$. Neurodegeneration $\cdot \beta$-Sheet

\begin{abstract}
Prion diseases in humans and animals comprise a group of invariably fatal neurodegenerative diseases characterized by the formation of a pathogenic protein conformer designated $\mathrm{PrPSc}^{\mathrm{Sc}}$ and infectious particles denoted prions. The cellular prion protein $\left(\mathrm{PrPC}^{\mathrm{C}}\right)$ has a central role in the pathogenesis of prion disease. First, it is the precursor of $\mathrm{PrPSC}^{\mathrm{Sc}}$ and infectious prions and second, its expression on neuronal cells is required to mediate toxic effects of prions. To specifically study the role of $\mathrm{PrPC}$ as a mediator of toxic signaling, we have developed novel cell culture models, including primary neurons prepared from PrP-deficient mice. Using these approaches we have been able to show that $\operatorname{PrP}^{C}$ can interact with and mediate toxic signaling of various $\beta$-sheet-rich conformers of different origins, including amyloid $\beta$, suggesting a pathophysiological role of the prion protein beyond prion diseases.

Copyright $\odot 2011$ S. Karger AG, Basel
\end{abstract}

\section{Results and Discussion}

$\operatorname{Pr} P^{C}$ Mediates Toxic Signaling of Homologous and Heterologous $\operatorname{Pr} P^{S c}$

By employing transgenic mice, it has been convincingly shown that the expression of $\operatorname{PrP}^{C}$ is essential for the formation of $\mathrm{PrP}^{\mathrm{Sc}}$ and infectious prions [1]. Moreover, neuronal $\mathrm{PrP}^{\mathrm{C}}$ is required to mediate neurotoxic effects of scrapie prions [2-4]. Using a novel cell culture model, we could corroborate that $\mathrm{PrP}^{\mathrm{C}}$ localized at the cell surface is a mediator of proapoptotic signaling induced by $\operatorname{PrP}^{\mathrm{Sc}}$ [5]. This assay is based on the cocultivation of $\mathrm{PrP}^{\mathrm{C}}$ expressing cells with scrapie-infected cells that release $\mathrm{PrP}^{\mathrm{Sc}}$ and infectious prions into the cell culture medium. To test whether the toxic effects required sustained de novo formation of $\mathrm{PrP}^{\mathrm{Sc}}$, we modified our cell culture model in order to minimize the possibility that propagation of infectious prions occurs. To this end, we exposed cells expressing hamster, human, cervid or bovine $\mathrm{PrP}^{\mathrm{C}}$ to mouse $\mathrm{PrP}^{\mathrm{Sc}}$. Based on previous studies in transgenic mice and cell culture models $[6,7]$, it is highly unlikely that mouse $\operatorname{PrP}^{\mathrm{Sc}}$ can induce efficient conversion of heterologous $\mathrm{PrP}^{\mathrm{C}}$ molecules into $\mathrm{PrP}^{\mathrm{Sc}}$. Strikingly, heterologous $\operatorname{PrP}^{\mathrm{C}}$, be it of hamster, human, cervid or bovine origin, could efficiently mediate toxic signaling of mouse 
$\mathrm{PrP}^{\mathrm{Sc}}$ in our model. These findings provided experimental evidence that toxic signaling of $\mathrm{PrP}^{\mathrm{Sc}}$ via $\mathrm{PrP}^{\mathrm{C}}$ appears to be independent of $\mathrm{PrP}^{\mathrm{Sc}}$ propagation [8].

\section{$\operatorname{Pr} P^{C}$ Binds to and Mediates Toxic Signaling of}

$\beta$-Sheet-Rich Conformers of Different Origins

Some observations already suggested a possible connection between Alzheimer's disease and prion diseases [9], but the first mechanistic insight into a possible role of $\mathrm{PrP}^{\mathrm{C}}$ in amyloid beta $(\mathrm{A} \beta)$-induced toxicity was provided by the Strittmatter group. They identified $\mathrm{PrP}^{\mathrm{C}}$ as a highaffinity receptor for oligomeric conformers of $A \beta$ and showed that expression of $\mathrm{PrP}^{\mathrm{C}}$ is required to mediate $\mathrm{A} \beta$ induced inhibition of long-term potentiation and memory impairment in transgenic Alzheimer mice [10, 11]. Initially, these results could not be reproduced by other groups [12-14]. However, in the meantime, independent studies, including one from our group, provided additional experimental evidence for the concept that $\mathrm{PrP}^{\mathrm{C}}$ can act as a mediator of $A \beta$-induced toxicity $[8,15-18]$.

In our study, we did not only focus on the role of $\operatorname{PrP}^{\mathrm{C}}$ as a possible mediator of $\mathrm{A} \beta$-induced toxicity, but we also addressed the possibility that $\operatorname{PrP}^{\mathrm{C}}$ can mediate toxic signaling of diverse $\beta$-sheet-rich conformers. In particular, we tested toxic assemblies formed by (a) A $\beta$ peptide, (b) the NM domain of the yeast prion protein Sup35 [19] and (c) designed $\beta$-sheet peptides [20]. Indeed, employing established cell lines and primary neurons prepared from wild-type or $\mathrm{PrP}^{0 / 0}$ mice, we could show that the expression of $\mathrm{PrP}^{\mathrm{C}}$ sensitizes cells to toxic effects of different $\beta$-sheet-rich conformers [8].

The mechanisms underlying the toxic activity of $\beta$ sheet-rich conformers are far from being understood, but it is conceivable that different upstream events converge at similar neurotoxic signaling pathways. We therefore started to define components downstream of $\mathrm{PrP}^{\mathrm{C}}$ involved in toxic signaling. Interestingly, $\mathrm{A} \beta-, \mathrm{PrP}^{\mathrm{Sc}}$ - and $\beta$-peptide-induced toxicity was significantly reduced by pharmacological blockage of N-methyl-D-aspartate re- ceptor activity. In addition, we observed that $\mathrm{PrP}^{\mathrm{Sc}}$ can induce mitochondrial alterations in neurons, such as perinuclear clustering of mitochondria.

Another important issue is to define domains of $\operatorname{PrP}^{\mathrm{C}}$ involved in signal transmission. This involves interactions of $\mathrm{PrP}^{\mathrm{C}}$ with the pathogenic protein assemblies and with cellular factors required for signal transmission. A consistent finding of different groups is that the primary binding site of oligomeric $A \beta$ lies within the intrinsically disordered $\mathrm{N}$-terminal domain of $\operatorname{PrP}^{\mathrm{C}}$. Further fine mapping indicated a prominent role of the region between amino acids 90 and 119 [10, 18, 21]. We could corroborate that $\operatorname{PrP} \Delta \mathrm{N}$, a mutant lacking a large portion of the $\mathrm{N}$-terminal domain, is impaired in both binding to $\mathrm{A} \beta$ and mediating its toxic effects. Moreover, a secreted version of the $\mathrm{N}$-terminal domain of $\mathrm{PrP}^{\mathrm{C}}$ efficiently interacted with $\beta$-sheet-rich conformers and interfered with toxic signaling via $\operatorname{PrP}^{C}$. However, binding of $\beta$ sheet-rich conformers to $\operatorname{PrP}^{\mathrm{C}}$ at the plasma membrane is not sufficient to induce toxic signaling. PrP-CD4, a PrP mutant anchored to the plasma membrane by a heterologous C-terminal transmembrane domain, binds to $\beta$ peptides but cannot mediate toxic effects. Thus, targeting of $\mathrm{PrP}^{\mathrm{C}}$ to specific microdomains by a GPI anchor could be a prerequisite to induce intracellular signaling pathways, for example via Fyn kinase $[8,22]$. While there is increasing support for a role of $\operatorname{PrP}^{\mathrm{C}}$ as a mediator of $\mathrm{A} \beta$ induced synaptic dysfunction, further research is required to better characterize the toxic protein assemblies and to identify the underlying mechanisms disrupting neuronal homeostasis.

\section{Acknowledgements}

Work of the authors was supported by grants from the Deutsche Forschungsgemeinschaft (SFB 596), the Max Planck Society and the BMBF (BioDisc, DIP5.1).

\section{References}

1 Büeler H, Aguzzi A, Sailer A, Greiner R-A, Autenried P, Aguet M, Weissmann C: Mice devoid of PrP are resistant to scrapie. Cell 1993;73:1339-1347.

2 Brandner S, Isenmann S, Raeber A, Fischer M, Sailer A, Kobayashi Y, Marino S, Weissmann C, Aguzzi A: Normal host prion protein necessary for scrapie-induced neurotoxicity. Nature 1996;379:339-343.
3 Mallucci G, Dickinson A, Linehan J, Klohn PC, Brandner S, Collinge J: Depleting neuronal $\mathrm{PrP}$ in prion infection prevents disease and reverses spongiosis. Science 2003;302: 871-874.

4 Chesebro B, Trifilo M, Race R, Meade-White K, Teng C, LaCasse R, Raymond L, Favara C, Baron G, Priola S, Caughey B, Masliah E, Oldstone M: Anchorless prion protein results in infectious amyloid disease without clinical scrapie. Science 2005;308:1435-1439. 
5 Rambold AS, Müller V, Ron U, Ben-Tal N, Winklhofer KF, Tatzelt J: Stress-protective activity of prion protein is corrupted by scrapie-prions. EMBO J 2008;27:1974-1984.

6 Scott MR, Safar J, Telling G, Nguyen O, Groth D, Torchia M, Koehler R, Tremblay P, Walther D, Cohen FE, DeArmond SJ, Prusiner SB: Identification of a prion protein epitope modulating transmission of bovine spongiform encephalopathy prions to transgenic mice. Proc Natl Acad Sci USA 1997;94: 14279-14284.

7 Scott M, Foster D, Mirenda C, Serban D, Coufal F, Walchli M, Torchia M, Groth D, Carlson G, DeArmond SJ, Westaway D, Prusiner SB: Transgenic mice expressing hamster prion protein produce species-specific scrapie infectivity and amyloid plaques. Cell 1989;59:847-857.

8 Resenberger UK, Harmeier A, Woerner AC, Goodman JL, Muller V, Krishnan R, Vabulas RM, Kretzschmar HA, Lindquist S, Hartl FU, Multhaup G, Winklhofer KF, Tatzelt J: The cellular prion protein mediates neurotoxic signalling of beta-sheet-rich conformers independent of prion replication. EMBO J 2011;30:2057-2070.

9 Resenberger UK, Winklhofer KF, Tatzelt J: Neuroprotective and neurotoxic signaling by the prion protein. Top Curr Chem 2011; 305:101-119.

10 Lauren J, Gimbel DA, Nygaard HB, Gilbert JW, Strittmatter SM: Cellular prion protein mediates impairment of synaptic plasticity by amyloid-beta oligomers. Nature 2009;457: $1128-1132$.
11 Gimbel DA, Nygaard HB, Coffey EE, Gunther EC, Lauren J, Gimbel ZA, Strittmatter SM: Memory impairment in transgenic Alzheimer mice requires cellular prion protein. J Neurosci 2010;30:6367-6374.

12 Balducci C, Beeg M, Stravalaci M, Bastone A, Sclip A, Biasini E, Tapella L, Colombo L, Manzoni C, Borsello T, Chiesa R, Gobbi M, Salmona M, Forloni G: Synthetic amyloidbeta oligomers impair long-term memory independently of cellular prion protein. Proc Natl Acad Sci USA 2010;107:2295-2300.

13 Calella AM, Farinelli M, Nuvolone M, Mirante $\mathrm{O}$, Moos R, Falsig J, Mansuy IM, Aguzzi A: Prion protein and Abeta-related synaptic toxicity impairment. EMBO Mol Med 2010;2:306-314.

14 Kessels HW, Nguyen LN, Nabavi S, Malinow $\mathrm{R}$ : The prion protein as a receptor for amyloid-beta. Nature 2010;466:E3-E4; discussion E4-E5.

15 Chung E, Ji Y, Sun Y, Kascsak RJ, Kascsak RB, Mehta PD, Strittmatter SM, Wisniewski $\mathrm{T}$ : Anti-PrPC monoclonal antibody infusion as a novel treatment for cognitive deficits in an Alzheimer's disease model mouse. BMC Neurosci 2010;11:130.

16 Caetano FA, Beraldo FH, Hajj GN, Guimaraes $\mathrm{AL}$, Jurgensen $\mathrm{S}$, Wasilewska-Sampaio AP, Hirata PH, Souza I, Machado CF, Wong DY, De Felice FG, Ferreira ST, Prado VF, Rylett RJ, Martins VR, Prado MA: Amyloidbeta oligomers increase the localization of prion protein at the cell surface. J Neurochem 2011;117:538-553.
17 Barry AE, Klyubin I, McDonald JM, Mably AJ, Farrell MA, Scott M, Walsh DM, Rowan MJ: Alzheimer's disease brain-derived amyloid- $\beta$-mediated inhibition of LTP in vivo is prevented by immunotargeting cellular prion protein. J Neurosci 2011;31:7259-7263.

18 Freir DB, Nicoll AJ, Klyubin I, Panico S, Mc Donald JM, Risse E, Asante EA, Farrow MA, Sessions RB, Saibil HR, Clarke AR, Rowan MJ, Walsh DM, Collinge J: Interaction between prion protein and toxic amyloid beta assemblies can be therapeutically targeted at multiple sites. Nat Commun 2011;2:336.

19 Li L, Lindquist S: Creating a protein-based element of inheritance. Science 2000;287: 661-664.

20 Olzscha H, Schermann SM, Woerner AC, Pinkert S, Hecht MH, Tartaglia GG, Vendruscolo M, Hayer-Hartl M, Hartl FU, Vabulas RM: Amyloid-like aggregates sequester numerous metastable proteins with essential cellular functions. Cell 2011;144: 67-78.

21 Chen S, Yadav SP, Surewicz WK: Interaction between human prion protein and amyloidbeta (Abeta) oligomers: role of $\mathrm{N}$-terminal residues. J Biol Chem 2010;285:26377-26383.

22 Mouillet-Richard S, Ermonval M, Chebassier C, Laplanche JL, Lehmann S, Launay JM, Kellermann O: Signal transduction through prion protein. Science 2000;289:1925-1928. 